\title{
DEBATES
}

\section{Representação politica e gastos orçamentários: um estudo sobre as ações e a politica orçamentária da câmara de vereadores de Erechim (RS)}

\section{Policy representation and budget expenditure: a study about the actions and budget policy of the city council of Erechim (RS)}

\author{
Eliziário Toledo \\ Giovanni Menegazzo \\ Humberto José da Rocha
}

\section{Resumo}

O estudo tem por objetivo analisar a atuação e a disponibilidade de recursos financeiros do Poder Legislativo do município de Erechim (RS). A análise da atuação foi realizada conforme as funçóes estabelecidas pela Controladoria Geral da Uniáo (CGU), enquanto a disponibilidade de recursos financeiros foi examinada de forma comparativa com municípios de população e localização geográfica similares, resultando em uma amostra composta por oito municípios, além de Erechim. Os dados foram observados de modo descritivo a partir da sua coleta nos portais de transparência de cada município. Os resultados da pesquisa apontam que $83 \%$ das açóes da Câmara Legislativa de Erechim não condizem com as funçóes estabelecidas pela CGU. Observou-se também que o orçamento, os gastos e o número de vagas no Legislativo de Erechim estáo acima da média dos demais municípios analisados, fatores que sugerem uma readequaçáo das açóes, do número de vagas e da política orçamentária do Legislativo de Erechim.

\section{Palavras-chave}

Orçamento Público; Democracia; Vereadores; Representaçáo.

\begin{abstract}
The study aims to analyze the performance and availability of financial resources of the Legislative Power of Erechim (RS). The analysis of performance was done according to the functions established by the Controladoria Geral da Uniâo (CGU), while the availability of financial resources was analyzed comparatively with cities of similar population and geographical location, resulting in a sample of eight cities in addition to Erechim. The data were observed in a descriptive way from their collection in the transparency portals of each municipality. The results indicate that $83 \%$ of the actions of the City Council of Erechim do not match the functions established by the CGU. It was also observed that the budget, expenses and number of vacancies in the Erechim legislature are higher than the average of the cities analyzed, a factor that suggest the need for a readjustment of the actions, vacancy number and budget policy of Erechim's Legislative Power.
\end{abstract}

\section{Keywords}

Public Budget; Democracy; Councilors; Representation. 


\section{Introdução}

No Brasil, é curta a trajetória de florescimento e consolidação da democracia: na história dos últimos 100 anos, a democracia se fez presente em pouco mais de 40 anos. Esse regime político é uma expressão do positivismo, dando preferência a sistemas de poder centralizados por meio de alianças com os poderes. Tanto o positivismo como o catolicismo conservador, ambos avessos a mudanças, bloquearam a emergência da diversidade social periférica. Como consequência, o Estado esteve, em geral, a serviço de uma elite, cujos interesses não republicanos protegeram seus benefícios e modos de vida, e moldou o coração e mentes dos brasileiros a não vislumbrar outras possibilidades; afinal, sempre foi assim.

Pode-se intuir que, com base nessa matriz de formação social e política, o brasileiro médio, em decorrência, seja, em sua maioria, de natureza conservadora e autoritária (DA MATTA, 1997). Por outro lado, há um forte apelo à vida familiar e comunitária, cuja rigidez dogmática e autoritária em princípio reproduziu nos indivíduos um padrão de subordinação ideológica (NAVARRO, 2017). Essa concepção foi traduzida sistematicamente no ideário político, mediante mecanismos dificultadores de apreensão, compreensão e acesso a espaços que pudessem garantir o controle social das instituiçóes políticas. Kothe (2017, p. 239) radicaliza ao afirmar que os brasileiros são "[...] assaltados por toda a parte, governados por políticos empenhados em garantir reeleições e boa vida para si do que com o bem comum”.

Essa armadilha histórica produziu uma sociedade ressentida, cujos sentimentos se cristalizaram na transferência de responsabilidades, complacência, subserviência, aversão e freio às mudanças, tão necessárias e por tantas vezes adiadas, pondo o brasileiro em marcha, por comodismo, lassidão ou descrença, a trabalhar contra si mesmo (NAVARRO, 2017). Esses comportamentos sociais podem ser traduzidos, em grande parte, na corrupção que gera continuamente a perda de credibilidade e confiança nas instituições públicas. Lógico, a perda de credibilidade, causada especialmente pela corrupção, má gestão, compadrio e clientelismo, não é um atributo exclusivamente brasileiro ou dos países em desenvolvimento. North (1990) defende que, nos países desenvolvidos, o fenômeno decorre de deficiências nos sistemas democráticos, enquanto nos países em desenvolvimento, a corrupção surge em decorrência das debilidades estruturais na formação das instituiçôes.

Infelizmente, no caso brasileiro, essa é uma faceta da realidade que não está restrita aos domínios da administração da máquina pública do Estado; esses vícios estão presentes, em maior ou menor grau, na maioria das organizaçôes da sociedade civil. É um fator que dificulta a emergência da cidadania. Benevides (1994, p. 45) 
enfatiza que "A cidadania é expressa num conjunto de direitos e deveres que permite aos cidadãos e às cidadâs o direito de participar da vida política e da vida pública, podendo votar e serem votados, participando ativamente na elaboração das leis e do exercício de funções públicas". $\mathrm{Na}$ tradição política brasileira, marcada pelo mandonismo (CARVALHO, 1997), clientelismo, insulamento burocrático (NUNES, 2003) e pelo presidencialismo de coalizão (ABRANCHES, 2003), a pressão do eleitorado sobre o parlamento ocorre em situações muito particulares (mobilização pelas Diretas Já, impeachment do presidente Fernando Collor de Mello em 1992 e da presidenta Dilma Roussef, expressa nas mobilizaçóes realizadas em junho de 2013).

Praticamente inexiste a pressão política consistente e sistemática da base eleitoral sobre o desenvolvimento do mandato dos parlamentares para outras questóes ordinárias, em fiscalizar as demagógicas "promessas de campanha”. Essa opção delega o direito permanente aos mediadores políticos eleitos para utilizar as instituições públicas para outros interesses ou em proveito particular, em detrimento do interesse público, por falta de fiscalização. É a expressão sui generis da política representativa “à brasileira", traduzida sob as distintas formas históricas do já citado mandonismo, clientelismo, insulamento burocrático e do presidencialismo de coalizão (CARVALHO, 1997; NUNES, 2003; ABRANCHES, 2003). Essas características de poder combinadas se manifestam sob o rótulo estamental do patrimonialismo histórico, em que o poder público se torna uma extensão do poder privado, percepção descrita ricamente por Faoro (2008) há mais de 60 anos. E esse processo se manifesta de forma heterogênea e diversificada nas distintas regióes brasileiras.

Não é de se admirar, portanto, que o processo de aprendizado da democracia do cidadão brasileiro seja insatisfatório. $\mathrm{O}$ conceito do que seja democracia ainda não foi devidamente apreendido pelo eleitor. A prática política tem demonstrado que a democracia quase sempre foi efetivada unicamente por meio do direito ao voto, como mecanismo e expressão principal da representação do poder político e econômico da sociedade. Hirschman (1983, p. 125-126) acredita que essa não é a principal limitação, "[...] mas o fato de tirar a legitimidade de outras formas mais diretas, intensas e 'expressivas' de ação política que, além de mais eficientes, são mais satisfatórias”. $\mathrm{Na}$ esteira das crises de credibilidade das instituiçôes democráticas, é no mínimo perturbador o enunciado de Zizek (2019, p. 55) de que "É a ilusão democrática, a aceitação de mecanismos democráticos como provedores da única estrutura para qualquer mudança possível, que impede a transformação radical da 
sociedade". Somente o direito de votar e ser votado, ter imprensa livre e ampla opiniáo crítica indicam não serem suficientes para promover as mudanças estruturais que a sociedade necessita.

Isso posto, ainda é escassa entre nós a noção básica de contribuinte, quiçá de cidadão. A vaga compreensão da ideia de contribuinte denota, na maioria das vezes, a quase totalidade de desconhecimento, entre as instâncias da administração (União, Estado e Município), dos elementos centrais do processo legislativo e da administração e gestão do Estado, como o Plano Plurianual (PPA), a Lei de Diretrizes Orçamentárias (LDO), a Lei de Responsabilidade Fiscal (LRF) e a Lei Orçamentária Anual (LOA). Os destinos e a condução dos assuntos do Estado são ocupados por uma elite política e econômica, que utilizam esses instrumentos à revelia da opinião pública, fazendo-os trabalhar a seu favor. Além disso, a qualidade e os limites da democracia são revelados e expressos por meio de leis casuísticas que alimentam o descontrole dos gastos públicos, à medida que ela necessita e é amparada pelos aportes do financiamento público, ou seja, dos contribuintes, mas sem controle efetivo destes.

O que se pretende analisar neste artigo é a atuação legislativa dos vereadores do município de Erechim (RS) a partir das funçóes legalmente atribuídas para legislar, fiscalizar e administrar e da disponibilidade de orçamento público alocado no âmbito municipal. Metodologicamente, foi utilizado o método comparado, considerando os percentuais anotados nos municípios de Bento Gonçalves (RS), Chapecó (SC), Concórdia (SC), Lages (SC), Lajeado (RS), Passo Fundo (RS), Pato Branco (PR) e Santa Cruz do Sul (RS). Os municípios foram escolhidos a partir das semelhanças populacionais com o município de Erechim.

A análise das matérias aprovadas se baseou na produção legislativa e nas informações expressas no site da Câmara de Vereadores de Erechim. As informações orçamentárias foram retiradas dos sites dos municípios citados no tocante aos percentuais destinados para o Legislativo Municipal, regidos pela Emenda Constitucional (EMC) n. ${ }^{\circ}$ 58, (BRASIL, 2009).

$\mathrm{O}$ artigo busca problematizar a relação entre o exercício dos vereadores por meio da produção legislativa e do gasto público disponibilizado pelo orçamento do município de Erechim (RS). Argumenta-se que há espaços razoáveis na redução de gastos abaixo daqueles estipulados pela legislação, quando comparados com outros municípios selecionados de populaçáo semelhante. Além disso, o estudo foi motivado pelo fato de que a Câmara de Vereadores de Erechim vem utilizando parcialmente o valor orçado. Esse fato abre espaço e sedimenta o debate sobre a diminuição dos gastos, na contramão do contínuo crescimento dos recursos orçamentários e na 
subsequente redução do número de vereadores.

Adotamos como metodologia o estudo comparado. Os dados foram analisados e interpretados de modo descritivo. Os municípios selecionados são semelhantes em população (entre 50 mil e 250 mil habitantes), com distâncias inferiores a $300 \mathrm{~km}$ do município de Erechim, tomando como referência os percentuais orçamentários alocados e destinados a cobrir os gastos financeiros das Câmara de Vereadores dos municípios de Bento Gonçalves, Lajeado, Passo Fundo e Santa Cruz do Sul, no Rio Grande do Sul; Chapecó, Concórdia e Lages, em Santa Catarina; e Pato Branco, no Paraná.

O texto está organizado em outras quatro seções além desta introdução: a primeira analisa a qualidade da produção legislativa e dos gastos orçamentários; a segunda trata da democracia e das demandas de financiamento público; a terceira versa sobre a produção legislativa dos vereadores de Erechim; e, por fim, são apresentadas as consideraçôes finais.

\section{A qualidade da produção legislativa e os custos para a sociedade}

É inegável que as proposições legislativas estão no cerne da democracia representativa. É por meio da atividade legislativa que se busca consolidar a premissa de produzir e resguardar direitos e produzir as obrigações consensuais na sociedade. Em face a esses objetivos, se evidencia a necessidade de estudo, pesquisa e debate no processo de elaboração das leis, sobre as quais repousam o desejo de justiça social, ordenamento e busca de segurança jurídica aos contratos, à propriedade privada e ao ambiente político, social e econômico do Estado. Além disso, é por meio das leis que se torna possível o funcionamento das instituições, cujos reflexos afetam a vida dos indivíduos e da sociedade. As leis se refletem na condução das políticas que orientam a educação, saúde, segurança pública, meio ambiente, mercado financeiro, tecnologia, agricultura e indústria. As leis regulam, da mesma forma, as organizaçóes privadas, públicas e os governos estaduais e municipais.

Mas a atividade e a qualidade legislativa são processos contraditórios e expõem em grande medida a qualidade cívica do cidadão, externalizando os valores morais que sedimentam a sociedade. Revelam, de igual forma, como os grupos sociais e econômicos se organizam para defender os interesses na arena política. Contudo, deve-se lembrar que a dinâmica social é continuamente mais célere que a produção das leis, as quais, desse modo, estão a reboque das demandas da sociedade. Esse fator 
expressa, de certa maneira, a incapacidade do Estado de normatizar todas as relaçóes da sociedade, sejam elas conflitivas ou não, a fim de proteger ou rechaçar interesses dos distintos grupos por meio da legislação, a qual por si só não garante os direitos. São necessárias lutas, pressão e vigilância constantes.

Por outro lado, avaliar a qualidade da produção legislativa não é uma tarefa trivial. A tentativa de tratar racionalmente a legislação por meio de processos objetivos encontra dificuldades, uma vez que as leis carregam em si dimensóes subjetivas, simbólicas e, por vezes, destinadas a atender um público em particular. As leis podem representar tentativas de reparar erros históricos e resgatar o reconhecimento social negligenciado; no entanto, podem expressar e manter preconceitos, discriminação e a manutenção de privilégios e interesses espúrios de qualquer ordem de determinado grupo social. E isso ocorre na medida em que manejam com mais habilidade e eficácia os recursos políticos, sociais e financeiros disponíveis. As leis revelam o processo de desenvolvimento de cada sociedade (MINAS GERAIS, 2009), demonstrado nos processos de avanço, estagnação, recuo e retrocesso.

As leis quase sempre reproduzem a ordem social de quem está no poder. Nesse cenário, as demandas da população em situação de vulnerabilidade e que não domina os meandros do poder têm poucas chances de ser ouvida e obter sucesso. Sen (2000) afirma que a pobreza é um dos fatores que diminui de maneira drástica a capacidade das pessoas de participar da vida democrática, na medida em que a busca imediata da sobrevivência se torna a única preocupação cotidiana. Em contrapartida, a principal prioridade do representante político é ampliar a capacidade de produzir justificação social na base eleitoral ao consagrar e legitimar as estratégias de cooptação dos votos do eleitorado. Isso ocorre porque as estratégias adotadas pelos representantes visam angariar ganhos eleitorais na arena política em curto prazo, como afirma Delley (2009), ao aludir que os políticos são pessoas apressadas. Surge aí o caminho aberto para o uso demagógico de soluçóes mágicas, que se concretizam por meio de promessas de campanha e por meio da edição de leis populistas e que desmobilizam a sociedade dos reais objetivos, o que é agravado pela ausência da crítica necessária.

Esses fatores influenciam, inclusive, as estratégias e as alianças construídas no preenchimento dos cargos para o assessoramento técnico, ou das cotas de cargos do partido de apoio ao Executivo, em que o principal critério é a filiação e a afinidade partidária, e não a capacidade acadêmica e técnica. Por outro lado, os partidos brasileiros, na maioria, não são tão democráticos quanto querem parecer. É comum 
os chefetes políticos transformarem "os técnicos" em militantes "carregadores de malas", anulando a capacidade de reflexão crítica sobre os projetos. Além disso, os representantes políticos buscam dar respostas (legislativas) a interesses específicos no calor dos fatos, frente às demandas emergenciais e premidos pelo clamor social de eventos de grande comoção (desastres, crimes violentos ou grandes mobilizações de rua, por exemplo). As leis oriundas desses eventos se revelam frequentemente inócuas e casuísticas, na medida em que enfatizam estratégias de pôr "panos quentes" nas demandas sociais. Delley (2009), nesse aspecto, é enfático ao evidenciar a ausência de clareza entre as relaçóes de causa e efeito expressas nas leis.

[...] os efeitos da lei daqueles que resultam de discursos sobre a lei. Toda lei é precedida de debate político, realizado pelo Parlamento, pela população, pela mídia, e uma boa parte dos efeitos resultam desses discursos, e não da lei. Essa questão não é insignificante, pois sabemos que os efeitos da lei, inicialmente, são simbólicos, ou seja, não resultam de seu conteúdo, e sim do fato de se anunciar que uma lei vai ser adotada. A arte da política, em grande parte, é a arte de anunciar, de dar satisfação à opinião pública. (DELLEY, 2009, p. 183).

Dessa forma, o objetivo expresso na lei busca responder a um conjunto variado de interpendências, mas o autor lembra que, independentemente desses fatores, a lei deve primar pela simplicidade, produzindo objetividade e praticidade da vida cotidiana. Por outro lado, a avaliação objetiva das demandas e dos comportamentos sociais é difícil de ser capturada pelos cientistas sociais e transformada em teorias. Entretanto, no caso da atividade legislativa, a função principal é a de legislar e a apresentar uma resposta institucional prática às questóes trazidas pelos distintos atores sociais, e não a verificação de uma teoria. $\mathrm{O}$ procedimento científico é a busca da verdade, mas o julgamento objetivo, nesses casos, é valorativo e dificilmente chegara ao termo explícito de verdade (DELLEY, 2009).

Não é difícil imaginar que, no Brasil, isso seja simbólico, visto que são raros os estudos empíricos e analíticos que oferecem alguma consistência sobre as necessidades e os impactos produzidos pelas leis e das práticas políticas presentes nas distintas realidades das comunidades nas regiôes brasileiras. Arretche (1998) enfatiza que a grande debilidade consiste precisamente em demonstrar analiticamente, que os resultados encontrados (seja o sucesso ou fracasso) estão casualmente relacionados aos 
produtos e bens públicos oferecidos e regulados por uma determinada lei sob análise. As leis deveriam expressar o sentimento e uma ideia de projeto político de nação. No Brasil, parece difícil situar essa missão. O que se imaginava ter sido evidenciado na Constituição Federal de 1988, foi uma miragem inebriante e um delírio fantasmagórico, criados metaforicamente para legislar direitos à um povo hipotético (MARTINS, 2017). A Constituição, no desejo mágico de recuperar o tempo perdido, de aplacar as injustiças e arbítrios cometidos nos "anos de chumbo", alocou energias excessivas no reconhecimento de direitos, e que não podem ser garantidos apenas por meio de leis e decretos. Olvidou-se, quase por completo, as necessidades e demandas por obrigações, em especial, o imperativo de vigiar e fiscalizar diuturnamente os representantes políticos.

Martins (2017, p. 154) enfatiza ainda que estamos afogados na cruzada cinzenta da eterna vítima, pois “[...] qualquer projeto político que se baseie na factibilidade é repudiado porque de direita. De esquerda é o sofrimento, a penúria, a cegueira, a alienação do conformismo e do inconformismo meramente verbal e queixoso". Kothe (2017, p. 118-119) é mais veemente ao afirmar que "[...] o brasileiro perdeu a guerra contra si mesmo. Não precisou de nenhum exército inimigo adentrando em seu território para ser derrotado. Ele foi incapaz de organizar e fazer funcionar bem seu aparelho de Estado e a sua economia". Para tanto, o cidadão deve deter conhecimento e disposição moral, necessários à construção de um projeto coletivo e mediado por algum condottiere, por ora, inexistente na arena política.

A Legística é a disciplina que estuda os processos de produção das leis para que sejam práticas e metódicas. $\mathrm{O}$ objetivo básico é aprimorar a qualidade por meio de técnicas e ferramentas adequadas à realidade social. O processo pode ser realizado utilizando avaliações legislativas antes ou depois da implementação da lei, e busca antecipar o impacto, a efetividade e a pertinência das leis mediante consultas à sociedade. Visa-se, assim, assegurar a transparência do processo legislativo e a participação efetiva (MENEGUIN, 2010). A técnica de redação legislativa deve produzir simplicidade, clareza e coerência dos textos legais (MINAS GERAIS, 2009), mas o que se observa são redaçóes confusas e herméticas, que parecem esconder o real objetivo e interesse do que está sendo legislado. $\mathrm{O}$ caso da redação dos orçamentos de financiamentos públicos é sintomático, tema a ser ampliado a seguir.

\section{A democracia e as demandas de financiamento público}

Talvez para os mais jovens, discutir a importância da democracia no Brasil já 
não faça tanto sentido; afinal, não viveram sob a sombra de regimes em que a reuniáo, o debate e o contraditório eram motivos de perseguição e cárcere. A democracia, ainda que não tenhamos claro o que seja realmente (NAVARRO, 2017, 2019), está se tornando um valor social e político. Se consolida por meio do direito à informação, ao voto, a opinar abertamente e a produzir direitos e obrigações, de forma que as críticas recorrentes ao modelo democrático, inclusive seus custos financeiros, lentamente auxiliam a transformá-lo e a melhorá-lo. O conceito de democracia aqui utilizado expressa o regime político constitucional em que todos os cidadãos adultos aptos votam mediante o sufrágio universal. As eleiçóes são livres, regulares e garantidas por uma constituição, que dá forma e conteúdo ao Estado democrático de direito, assegura a liberdade de associação, de expressão e de informação e a proteção aos direitos fundamentais das minorias (BRESSERPEREIRA, 2011).

É possível afirmar que a expansão do capitalismo liberal possibilitou o desenvolvimento da democracia e a ampliação de seus domínios expressos na forma de um "bom Estado" e de um governo. Esses fatores lograram compatibilizar a estabilidade política, assim como o alargamento de conquistas dos outros objetivos políticos nas sociedades modernas (BRESSER-PEREIRA, 2011). Logicamente, esses caminhos não foram e nem são uniformes, únicos e lineares, e expressam os percursos e as narrativas históricas singulares de cada sociedade. A democracia permitiu ampliar os domínios da propriedade privada e do mercado ao consentir a livre concorrência intercapitalista e viabilizar a acumulação da riqueza privada, mas que, na maioria das vezes, é capturada e aproveitada seletiva e desigualmente por uma parcela restrita da população com capacidade de exercer cidadania.

É pertinente o comentário de Zizek (2019, p. 41) ao aludir que, na atualidade, "[...] a democracia está prioritariamente regida e dominada pela ditadura dos mercados, o plebiscito permanente das flutuaçóes do mercado. O espaço para os agentes políticos democraticamente eleitos tomarem decisóes é muito limitado". Esse argumento evidencia a crise da representação democrática, que se transforma em mais uma modalidade competitiva e concorrencial. A atividade parlamentar, no caso brasileiro, se tornou uma fonte de que reproduz a desigualdade, o enriquecimento e a acumulação privada, e que ocorre por vias lícitas e ilícitas, tema amplamente veiculado na imprensa. Esses fatores, salvo exceções, entre outros, vêm mantendo quase inalterados os parâmetros da desigualdade, injustiça social e os níveis da corrupção que regem e são mantidos por parte expressiva da sociedade brasileira. 
O Congresso Nacional, bem como outras estruturas que se viabilizam por meio da separação e a interpendência com outros poderes (Executivo e Judiciário), é financiado com os recursos da sociedade por meio dos impostos arrecadados. A Lei de Responsabilidade Fiscal regulamenta os percentuais do orçamento da União, dos Estados e dos Municípios destinados a financiar os respectivos Poderes Legislativos. $\mathrm{Na}$ esfera federal, são destinados até 2,5\% da Receita Corrente Líquida (RCL), inclusas as despesas do Tribunal de Contas da Uniáo; na esfera estadual, até 3\% para agregados com o Tribunal de Contas do Estado. Na esfera municipal, o financiamento das necessidades dos respectivos Poderes Legislativos obedece o percentual de até $7 \%$ para municípios com população de até 100.000 habitantes; $6 \%$ para municípios com população entre 100.001 e 300.000; 5\% para municípios com população entre 300.001 e $500.000 ; 4,5 \%$ para municípios com população entre 500.001 e 3.000.000; $4 \%$ para municípios com população entre 3.000 .001 e 8.000.000; e 3,5\% para municípios com população acima de 8.000.001 habitantes (BRASIL, 2000, 2009).

O Orçamento Geral da União para o exercício de 2019, constante no Projeto de Lei Orçamentária Anual (PLOA), alocou R\$ 10.366,5 bilhóes (Câmara dos Deputados, R\$ 6.039,9 bilhões e o Senado Federal, R\$ 4.324,1 bilhões) (BRASIL, 2019), cerca de $\mathrm{R} \$ 17,45$ milhóes disponibilizados para cobrir os gastos de cada parlamentar. Nesse valor, não estão incluídos os $\mathrm{R} \$ 2.050,1$ bilhôes destinados ao Tribunal de Contas da União como despesa do Legislativo. Além disso, as demandas políticas dos parlamentares (as emendas) são amparadas pelo Orçamento Impositivo, protegido pela Emenda Constitucional n. ${ }^{\circ}$ 86, de 17 de março de 2015 (BRASIL, 2015). O volume previsto de recursos para 2019 é de $R \$ 13,7$ bilhóes, sendo $R \$ 9,2$ bilhôes para as emendas individuais (deputados e senadores). As emendas individuais contemplam pleitos e demandas das "bases eleitorais", e cada um dos 594 parlamentares poderá apresentar até R \$ 15,4 milhões em emendas (BRASIL, 2018a). As bancadas têm mais $\mathrm{R} \$ 4,5$ bilhóes para apoiar as emendas de bancadas (BRASIL, 2019).

Além disso, foram disponibilizados recursos oriundos do Orçamento Geral da União para apoio à democracia: R \$ 888,7 milhões para o Fundo Partidário, e, para o Fundo Especial de Financiamento de Campanha (FEFC), R\$ 1.716.209.431,00, valores esses que devem ser transferidos aos diretórios nacionais dos 35 partidos com registro no Tribunal Superior Eleitoral (TSE) (BRASIL, 2018c) para apoiar as eleições.

Outro aspecto da pesquisa se fixa na análise do pagamento dos salários aos 
parlamentares (Figura 1). Nem mesmo as recorrentes crises econômicas e sociais na América Latina têm sido argumento consistente para diminuir a disparidade entre os ganhos dos parlamentares e o salário médio dos cidadãos que eles dizem representar. Os salários pagos aos parlamentares brasileiros são maiores do que aqueles pagos em países da Europa, nos Estados Unidos e no Japão. Os dados tabulados pela Deutsche Welle, (QUANTO..., 2018) apresentam o Brasil com o terceiro maior rendimento salarial pago aos parlamentares dos países latinos citados, com salários de US\$ 16.462,00 mensais. Esse valor é superior ao salário pago aos congressistas da Câmara dos Representantes dos Estados Unidos, com US\$ 14.500,00; do Japão, com rendimento mensal de US\$11.916,00; da Austrália, com US\$ 12.500,00; da Alemanha, com US\$ 11.000,00; da França, com US\$ 8.300,00; e do Reino Unido, com US\$ 8.250,00.

Figura 1 - Salário mensal dos parlamentares dos países selecionados (em dólares norte-americanos)

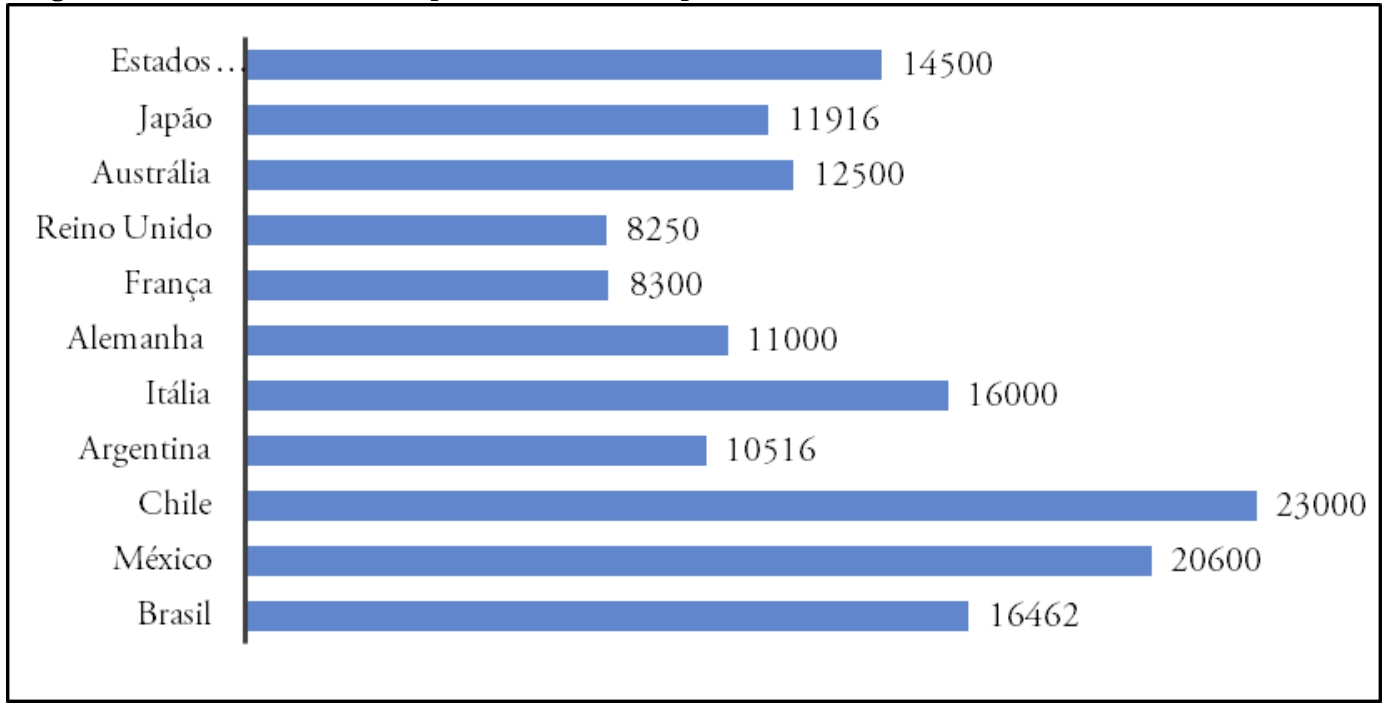

Fonte: Quanto... (2018).

Nota: Verbas complementares (Cota para Exercício da Atividade Parlamentar, recursos destinados a contratação de pessoal, auxílio moradia, despesas com saúde, cota gráfica, ajuda de custo e aposentadoria) somam cerca de R 2,2 milhôes por ano (BRASIL, 2018b).

O Chile é o país latino que tem o maior rendimento pago aos parlamentares, com US\$23.000,00 mensais, e o México figura em segundo, com US\$20.600,00. $\mathrm{Na}$ Argentina, os salários são de US\$ 10.516,00 mensais. Os dados parecem confirmar que, nos regimes democráticos consolidados há mais tempo, os cidadãos, 
de alguma forma, conseguiram por meio efetivo de fiscalização, de transparência e pressáo sobre os parlamentos, manter um relativo controle sobre os salários e vantagens pagos aos parlamentares.

Com relação às informações da Figura 1, cabe um comentário adicional. A saúde das instituiçôes em regimes democráticos depende muito da qualidade cívica dos cidadãos. São eles que têm possibilidade de gerar intuições (regras) sólidas, para que o sistema democrático representativo seja capaz de firmar o contrato social entre os cidadãos e o Estado por meio dos líderes políticos eleitos. Baquero e Vasconcelos (2013) defendem que o apoio ao sistema político ocorre na medida em que os gestores públicos oferecem e garantem determinados benefícios, tais como: a paz, a prosperidade, a responsividade governamental e a liderança confiável e competente. $\mathrm{Na}$ outra ponta, espera-se que os líderes e representantes políticos se mantenham dentro dessas exigências, e é nessa perspectiva que os cidadãos apoiam e concordam em obedecer ao contrato social vigente (ROSENTONE, LAZARUS, 1984).

No Brasil, os compromissos acima elencados ainda são uma aventura, uma vez que a nossa jovem democracia não logrou produzir, até o momento, institucionalidade segura. Os partidos políticos são frágeis, descolados da realidade e comandados com mão de ferro por "caciques”. Os programas partidários, por outro lado, são "promessas" que valem até a tomada do poder e, logo depois, são invariavelmente esquecidos. Em contrapartida, em nível local, a proximidade e a relação pessoal com os representantes legislativos poderiam ser elementos fundamentais para a produção de leis estruturantes e destinadas, prioritariamente, a atender às demandas coletivas por meio da melhor utilização dos gastos do Legislativo (o tema a ser tratado na sequência), mas a realidade da condução política não infere essa certeza.

\section{Gastos orçamentários do Legislativo de Erechim e outros}

O município de Erechim está localizado na região do Alto Uruguai, no Estado do Rio Grande do Sul. É a segunda cidade mais populosa do norte gaúcho, com uma estimativa de 105.059 habitantes, segundo dados estimados pelo IBGE (2018). Além disso, pelo Índice de Desenvolvimento Socioeconômico (IDESE), é a segunda cidade mais desenvolvida do Rio Grande do Sul entre os municípios com mais de 100 mil habitantes. No cenário geral das grandes cidades do Estado, nos aspectos de saúde e renda, Erechim se destaca com alto Índice de Desenvolvimento Humano $(0,820)$. Seu orçamento previsto na Lei Orçamentária Anual para 2019 é de R\$ 305.000.000,00 (ERECHIM, 2019). 
O estudo comparado adotado neste artigo, em relação à escolha dos sujeitos de pesquisa, à populaçáo e à amostra, coleta, tabulação e à análise de dados, visa garantir características similares entre os municípios a serem contemplados (Tabela 1). Definiu-se como critérios principais para a seleção: a população (entre $50 \mathrm{mil} \mathrm{e}$ 250 mil habitantes), a localização geográfica com distâncias inferiores a $300 \mathrm{~km}$ do município de Erechim (RS) e os percentuais orçamentários legais destinados à Câmara de Vereadores, selecionando-se, assim, além de Erechim, os municípios Bento Gonçalves, Lajeado, Passo Fundo e Santa Cruz do Sul, no Rio Grande do Sul; Chapecó, Concórdia e Lages, em Santa Catarina; e Pato Branco, no Paraná. Portanto, obteve-se uma amostra composta por oito municípios, além de Erechim.

Tabela 1 - Municípios selecionados considerando a população, o percentual legal do orçamento municipal para a Câmara de Vereadores e a distância de Erechim

\begin{tabular}{l|l|c|c|c}
\hline \multirow{4}{*}{ Estados } & Município & $\begin{array}{c}\text { População } \\
\text { (habitantes) }\end{array}$ & $\begin{array}{c}\text { \% legal para a } \\
\text { Câmara de } \\
\text { Vereadores* }\end{array}$ & $\begin{array}{c}\text { Distância de } \\
\text { Erechim (km) }\end{array}$ \\
\hline \multirow{4}{*}{$\begin{array}{l}\text { Rio Grande } \\
\text { do Sul }\end{array}$} & Erechim & 105.059 & 6 & - \\
\cline { 2 - 5 } & Bento Gonçalves & 119.049 & 6 & 251 \\
\cline { 2 - 5 } & Lajeado & 82.951 & 7 & 260 \\
\cline { 2 - 5 } & Passo Fundo & 201.767 & 6 & 296 \\
\cline { 2 - 5 } & Santa Cruz do Sul & 129.427 & 6 & 99 \\
\hline \multirow{2}{*}{$\begin{array}{l}\text { Santa } \\
\text { Catarina }\end{array}$} & Chapecó & 216.654 & 6 & 295 \\
\cline { 2 - 5 } & Concórdia & 74.106 & 6 & 236 \\
\cline { 2 - 5 } & Lages & 157.743 & 7 & \\
\hline \multirow{2}{*}{ Paraná } & Pato Branco & 81.893 & & 72 \\
\hline \multirow{2}{*}{ Fonce }
\end{tabular}

Fonte: IBGE (2018). *(BRASIL, 2000, 2009).

A análise descritiva dos dados foi feita a partir da coleta de informações nos portais de transparência de cada município. Em seguida, criou-se indicadores de eficiência (percentual do orçamento para a Câmara de Vereadores) relativos ao uso de recursos financeiros pelo Poder Legislativo, para então comparar os índices de Erechim com os demais municípios selecionados. Posteriormente, elaborou-se um novo índice de Erechim (o índice ajustado), utilizando como referência o índice médio dos municípios selecionados, para enfim, comparar o índice real de Erechim com o índice ajustado. Para determinar o valor ajustado para o orçamento da Câmara Municipal de Erechim, utilizou-se como referência a média dos orçamentos alocados 
para as câmaras dos demais municípios analisados em função do número de seus vereadores e habitantes.

A Figura 2 demonstra que, em 2018, a Câmara de Vereadores de Erechim foi contemplada com $3,7 \%$ do orçamento (podendo chegar até $6 \%$ na norma legal), (BRASIL, 2009), enquanto a média dos municípios analisados foi de 2,4\%. A taxa mais elevada, depois de Erechim, foi Passo Fundo, com 3,3\% do orçamento público municipal destinado ao Poder Legislativo, enquanto o previsto em lei foi de até $6 \%$. Em relação aos demais municípios, Bento Gonçalves ficou 2,3\% (até 6\% na norma legal), Chapecó 1,5\% (até 6\%), Lages 2,6\%, (6\%), Lajeado 2,6\%, (até 7\%) e Pato Branco 2,3\%, (até 7\%).

Figura 2 - Orçamento do Poder Legislativo para 2019 (\%) nos municípios selecionados

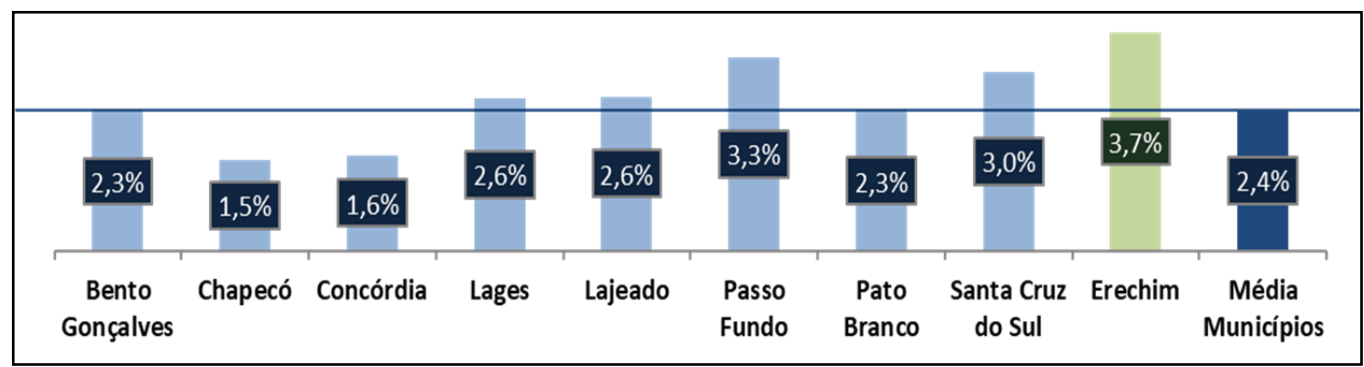

Fonte: Erechim (2019), Bento Gonçalves (2018), Chapecó (2019), Concórdia (2018), Lajeado (2018), Lages (2018), Passo Fundo (2018), Pato Branco (2019) e Santa Cruz do Sul (2018).

Os dados sugerem que os municípios de Santa Catarina e do Paraná são mais modestos quando se trata de destinar recursos para os gastos do Legislativo Municipal. Acenam com potencial para a redução de percentuais alocados ao Legislativo dos municípios que designam mais do que $1,5 \%$ da sua receita líquida. $\mathrm{Na}$ média dos últimos quatro anos, o Legislativo de Erechim deixou de utilizar em média 29\% dos recursos. A Câmara de Vereadores de Erechim não tem utilizado integralmente do valor orçado, mesmo assim, chama a atenção o fato de o orçamento alocado estar acima da média dos demais municípios. Enquanto o orçamento da Câmara de Vereadores de Erechim é de R\$ 11,2 milhões para 17 vereadores, o orçamento municipal de 2019 é de R \$ 305 milhôes. Já a Câmara de Vereadores de Chapecó possui um orçamento de $\mathrm{R} \$ 15,7$ milhóes para 21 vereadores, e o orçamento municipal para 2019 é de mais de R\$ 1 bilhão, o que representa mais que o triplo do orçamento municipal de Erechim. 
No caso do município de Erechim, entende-se a opção pela estratégia de estabelecer 61,6\% do teto, conforme a EMC n. ${ }^{\circ}$ 58/2009, (BRASIL, 2009) para retornar as sobras ao erário ao final do exercício. Entretanto, a opção de garantir o teto orçamentário, além de amenizar o potencial comprometimento quanto ao controle de gastos dos recursos públicos, também congela os recursos. Isso prejudica o planejamento financeiro do Poder Executivo, visto que a parte do valor não utilizada poderia ter seu destino vinculado à demandas do Executivo de forma antecipada, no início de cada exercício para outras necessidades da comunidade. Além disso, atentase para a possibilidade de utilizar o proselitismo político ao "devolver" recursos ao Poder Executivo que, já de antemão, não seriam utilizados.

Os dados da Figura 2 mostram os percentuais alocados, que, em 2015, foi de 3,8\%, em 2012, de 3,5\%, 2017, 3,4\%, 2018, 3,9\%, e em 2019 de 3,7\%. Em uma primeira observação, enfatiza-se o crescimento em termos percentuais da taxa do orçamento público municipal destinado à Câmara de Vereadores em 2018 em relação a $2017(+15,63 \%)$.

Figura 2 - Orçamento destinado à Câmara de Vereadores do município de Erechim (\%)

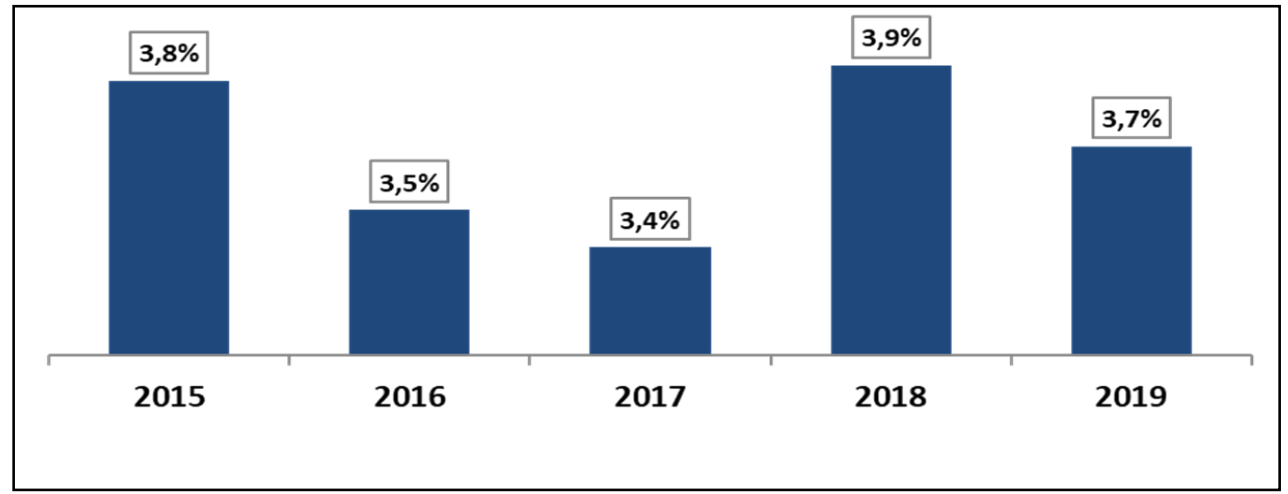

Fonte: Erechim (2018).

Entretanto, a fixação dos percentuais não parece utilizar nenhum parâmetro técnico (IPCA ou outros), e sim políticos. Além disso, nota-se que o valor orçado nos últimos anos pela Câmara de Vereadores é utilizado parcialmente (Tabela 2). Esse fator revela que os valores nominados estão acima das reais necessidades para o funcionamento da casa legislativa, embora, admitindo que estejam abaixo do teto previsto em lei, mas que poderiam ser reduzidos, alocando os recursos para outras 
necessidades da administração.

No exercício de 2015, foram orçados $\mathrm{R} \$ 8.300 .000,00$ em recursos, dos quais foram utilizados $\mathrm{R} \$ 6.051,345,00$ (-27,09\%); em 2016, foram alocados $\mathrm{R} \$$ 8.800.000,00 e utilizados R\$ 6.615,955,00 (-24,82\%); em 2017, foram R\$ 9.600.000,00 e utilizados R \$ 6.746.380,00 (-29,73\%); e, em 2018, foram orçados $\mathrm{R} \$ 11.100 .000,00$, dos quais foram efetivamente usados $\mathrm{R} \$ 7.132 .082,00$ ($35,75 \%)$. Para o exercício de 2019 , a proposta orçamentária inicialmente apresentada pela Câmara de Vereadores foi de $\mathrm{R} \$ 15.300 .000,00$, depois ajustada para $\mathrm{R} \$$ 11.220.000,00, dos quais foram utilizados 31,95\%. Por outro lado, o orçamento de 2015 para 2019 foi de 73,9\% na proposta ajustada (ERECHIM, 2018).

Tabela 2 - Recursos destinados à Câmara de Vereadores de Erechim entre 2015 e 2019 (orçado e realizado $R \$$ )

\begin{tabular}{r|c|r|r|c|c|r}
\hline Ano & Desp. orçada & \% diferença & IPCA (\%) & $\begin{array}{c}\text { Desp. } \\
\text { realizada }\end{array}$ & $\begin{array}{c}\text { Diferença } \\
(\mathrm{R} \$ \mathbf{)}\end{array}$ & $\begin{array}{r}\text { \% náo } \\
\text { utilizado }\end{array}$ \\
\hline 2019 & $11.220 .000,00$ & 1,08 & 3,78 & $7.621 .930,18$ & $3.578 .069,82$ & 31,95 \\
\hline 2018 & $11.100 .000,00$ & 15,63 & 2,86 & $7.132 .082,00$ & $3.967 .918,00$ & 35,75 \\
\hline 2017 & $9.600 .000,00$ & 9,09 & 5,35 & $6.746 .380,00$ & $2.853 .620,00$ & 29,73 \\
\hline 2016 & $8.800 .000,00$ & 6,02 & 10,71 & $6.615 .955,00$ & $2.184 .045,00$ & 24,82 \\
\hline 2015 & $8.300 .000,00$ & $\begin{array}{r}\text { Média }= \\
7,9 \%\end{array}$ & $\begin{array}{r}\text { Média }= \\
5,6 \%\end{array}$ & $6.051 .345,00$ & $2.248 .655,00$ & 27,09 \\
\hline
\end{tabular}

Fonte: Erechim (2018, 2019).

Nos casos aqui apresentados, conforme Figura 3, os critérios da EMC n. ${ }^{\circ}$ 58/2009 (BRASIL, 2009) estipularam: a) 15 vereadores nos municípios de 50 mil até 80 mil habitantes (Concórdia, SC, optou por 13); b) 17 vereadores nos municípios de mais de 80 mil até 120 mil habitantes (Bento Gonçalves e Erechim, RS, com 17, Pato Branco, PR, optou por 11, e Lajeado, RS, por 15); c) 19 vereadores nos municípios de mais de 120 mil até 160 mil habitantes (Santa Cruz do Sul, RS, optou por 17 vereadores, e Lages, SC, por 16); d) 21 vereadores nos municípios de mais de 160 mil a 300.000 habitantes (o caso de Chapecó, SC, e Passo Fundo, RS optaram pelo máximo, de 21). Verifica-se, ainda, com base nas informaçóes da Figura 3, que, dos nove municípios analisados, quatro utilizam o número máximo permitido para vereadores: Passo Fundo, Chapecó, Bento Gonçalves e Erechim.

Quando a análise se descola para o número de vereadores eleitos em relaçáo à população, observa-se que o número de habitantes por vereador auxilia na reflexão sobre a readequação do número de vereadores para cada município. Com efeito, a 
Figura 4, informa que Chapecó (SC) possui o maior número de habitantes por vereador (10.317), enquanto Erechim (RS) possui o terceiro menor índice, com 6.180 habitantes por vereador, abaixo da média (7.884 habitantes por vereador).

Figura 3- Número de vereadores para os municípios selecionados

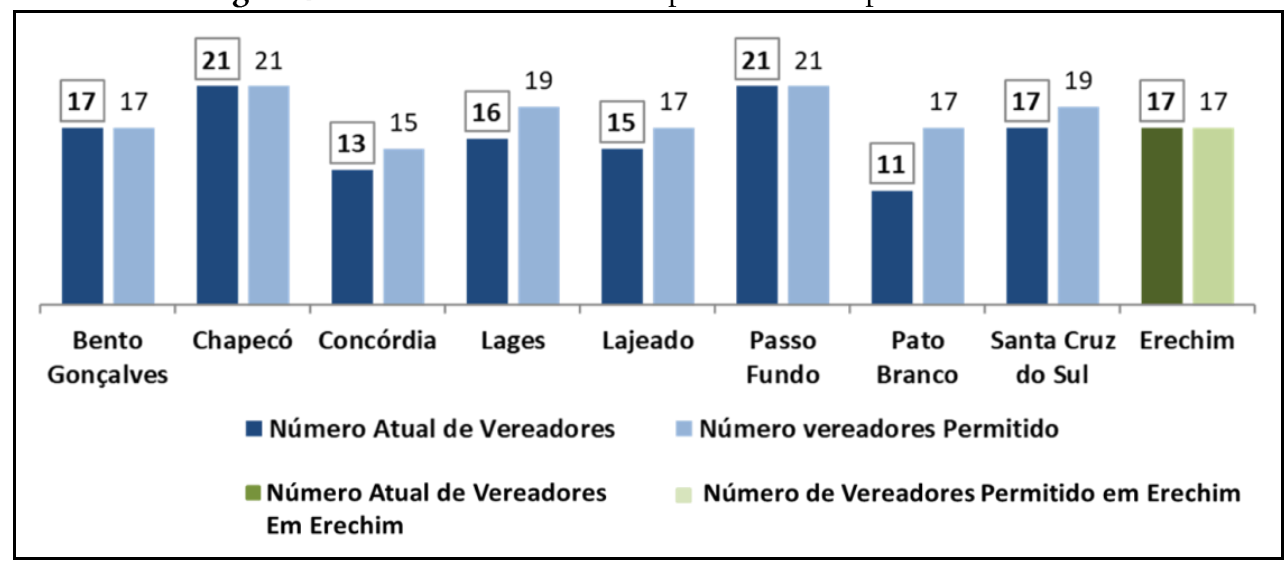

Fonte: EMC n.o 58/2009, (BRASIL, 2009).

Para elevar a média, os dados demonstram que há espaço para reduzir o número de vereadores nos municípios de Bento Goncalves, Concórdia, Lajeado, Pato Branco, Santa Cruz do Sul e Erechim. Os números demonstram que a adoção de critérios tomando unicamente por base os parâmetros descritos na EMC n.o 58/2009 (BRASIL, 2009), ou seja, utilizando apenas os intervalos populacionais, apresenta distorçôes que poderiam ser corrigidas adotando-se, por exemplo, a proporcionalidade. Se a média de habitantes por vereador em Erechim (6.180) fosse igual à média dos municípios analisados (7.884 habitantes por vereador), o Legislativo de Erechim seria composto por 14 vereadores.

Gráfico 4- Número de habitantes para cada vereador nos municípios selecionados

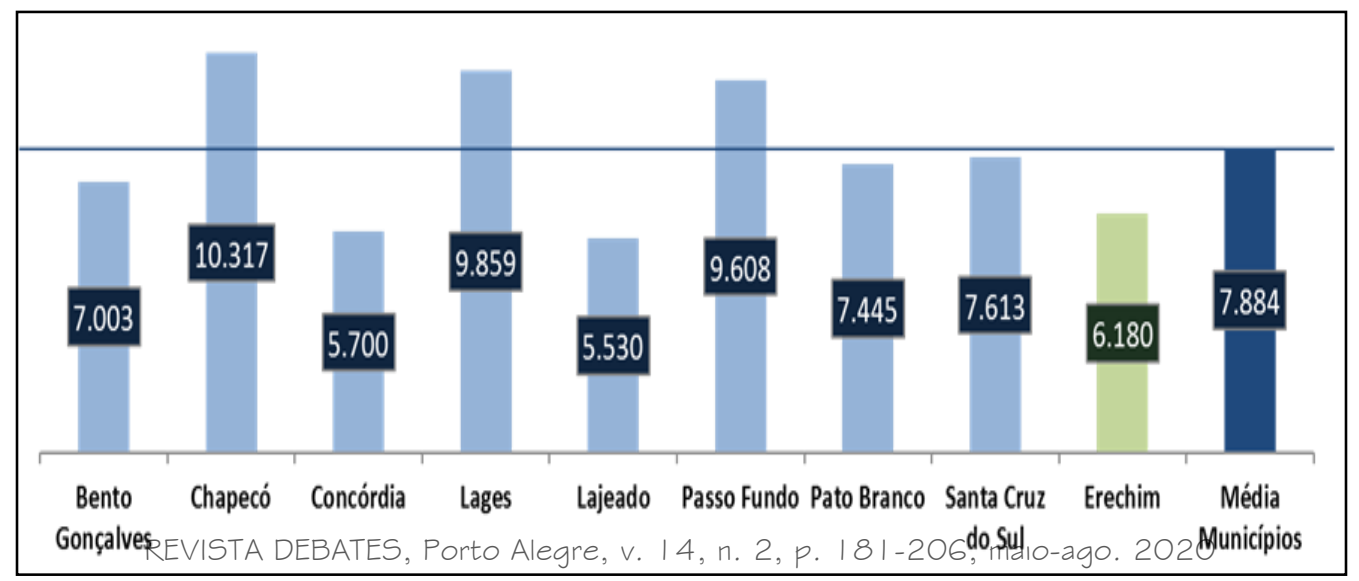


Fonte: Elaborado pelos autores.

Para efeitos de legitimidade e representatividade de seu exercício, a democracia não deveria ser pautada preferencialmente em aspectos econômicos, mas no bem coletivo e melhor administração dos recursos dos impostos gerados pela sociedade. Contudo, com a introdução da remuneração pela Constituição Federal de 1988 e da transferência de vantagens econômicas e simbólicas, a disputa e a atividade parlamentar se tornaram uma atividade elitista, competitiva e profissional, em que os setores mais organizados econômica e politicamente dominam o jogo e a regras do jogo. Essas constataçôes afetam, sobretudo, a qualidade da democracia e da produção legislativa, tema a ser ampliado na seção seguinte.

\section{A "produção legislativa" dos vereadores de Erechim}

Um documento elaborado pela Controladoria Geral da União (CGU) destaca as principais funçôes dos vereadores no exercício de seus mandatos. A primeira delas é a legislativa, relativa a elaborar, apreciar, alterar ou revogar as leis de interesse do município, que podem ter origem nas iniciativas dos próprios vereadores, do prefeito ou, ainda, da sociedade, por meio de projetos de iniciativa popular. A segunda é função fiscalizadora dos atos do Executivo e da burocracia municipal, por meio do acompanhamento e da implementação das decisões tomadas no âmbito do governo e da administração municipal, conforme o expresso no art. 31 da Constituição (BRASIL, 1988). A terceira é a função administrativa, destinada a exercer o gerenciamento do orçamento, do patrimônio, do pessoal e da organização dos serviços, como a composição da Mesa Diretora, a coordenação, o funcionamento das comissões etc. (CGU, 2011). A quarta função é a função julgadora, como, por exemplo, julgar o prefeito por crime de responsabilidade, além de julgar os próprios vereadores, inclusive o presidente da Câmara, em caso de irregularidades ou por falta de decoro parlamentar.

Neste estudo, as ações que não se enquadraram nas funçôes anteriormente mencionadas foram classificadas como "outras". Isso significa que essas açôes não são atribuições fundamentais dos vereadores segundo as recomendações elaboradas pela CGU. São as moçôes de apoio, honrarias, congratulaçôes, solicitações de sinalização, asfaltamento e operação tapa-buraco de vias, entre outros. Com essas diretivas, procedeu-se ao levantamento das ações do Legislativo de Erechim, classificando as açóes dos vereadores em exercício na atual gestão no período de $1^{\circ}$ de janeiro de 2017 a 31 de dezembro de 2018, conforme registradas pelos respectivos gabinetes no site 
da Câmara. Vale destacar que, neste estudo, não está sendo considerada a relevância de cada ação, como, por exemplo, o teor e a importância das leis e seus possíveis impactos à população, mas somente a quantidade de ações realizadas, classificando-as de acordo com as atribuições estabelecidas pela CGU.

A Figura 5 apresenta a "produção legislativa" dos vereadores de Erechim no período supracitado. Nesse contexto, observou-se que $11 \%$ das açóes foram classificadas como funçôes precípuas e pertinentes de legislar, ou seja, dedicadas à produção de leis ordinárias necessárias para o funcionamento da máquina pública ou para atender as demandas da comunidade. A função de fiscalização ocupou $6 \%$ das ações realizadas.

Figura 5 - Ações legislativas dos vereadores de Erechim (RS) de janeiro de 2017 a dezembro de 2018

Fonte: Erechim (2019).

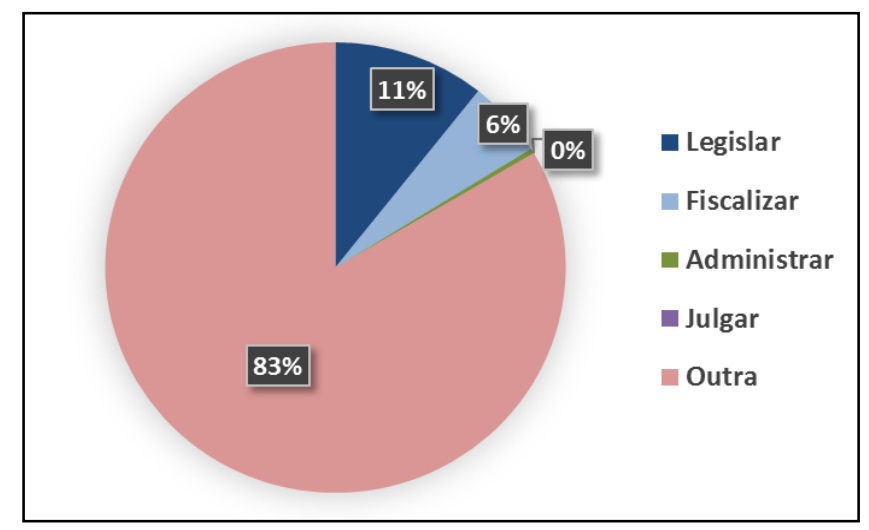

As duas funçôes (legislar e fiscalizar) representaram 17\% do total de 1.621 ações do período, enquanto a função "outras" representou $83 \%$ das ações. Isso revela a necessidade de compreender as relaçôes políticas estabelecidas entre o Poder Legislativo e o Poder Executivo municipais. Basicamente, os eleitores exercem uma influência maior devido à proximidade, às relaçóes pessoais e ao espaço reduzido de cada município e pressionam o "atendimento" das suas demandas particulares na atuação dos vereadores (LOPEZ, 2004).

\footnotetext{
1 Para conformar a ideia de "demanda" dos eleitores, Lopez (2004) estudou a Câmara Municipal de Umuarama (PR) por meio da análise de entrevistas com os vereadores, assessores, ex-prefeitos e funcionários do Legislativo e do Executivo, consultas ao Arquivo Público, jornais da região e observaçóes participantes diárias da atividade política de vereadores.
} 
Os dados da Figura 5 traduzidos sob a função "outras" permitem aludir à importância das demandas pessoais e particulares resultantes do embate direto do eleitor com os vereadores locais. Essas demandas particulares podem ser transformadas em possibilidades de justificação e cooptação política por meio de votos no próximo pleito. A capacidade de responder positivamente depende, em grande parte, do relacionamento "amistoso e apoiador" do vereador e do bloco de apoio parlamentar ao chefe do poder Executivo.

No caso de Erechim, o partido do prefeito tem apenas um vereador (PSDB), por extensão, o prefeito necessita estabelecer estratégias a fim de formar uma base parlamentar mínima, que pode ser conseguida por ocupação de cargos de confiança. Contudo, não levantamos elementos que permitam abonar se os parlamentares que votam com o Executivo têm mais sucesso no "atendimento" das demandas desses vereadores.

A Tabela 3 mostra a composição partidária do Poder Legislativo Municipal de Erechim na atual legislatura (2017-2020) é formado pelos 17 vereadores.

Tabela 3 - Composição partidária da Câmara de Vereadores de Erechim, gestão 2017-2020

\begin{tabular}{c|c}
\hline Partido político & Número de parlamentares \\
\hline MDB & 4 \\
\hline PT & 3 \\
\hline PP & 3 \\
\hline PSB & 1 \\
\hline PDT & 1 \\
\hline PTB & 1 \\
\hline PSDB & 1 \\
\hline PRB & 1 \\
\hline SD & 1 \\
\hline PCdoB & 1 \\
\hline Total & 17 \\
\hline
\end{tabular}

Fonte: Erechim (2020).

Vale salientar que a perspectiva de apoio ou de oposição tende a ser uma relação que estimula a adoção do "cálculo político" pendular, que inclui possibilidades de ponderaçáo sobre as maiores probabilidades de gerar votos. Sáo as demandas "das bases eleitorais" que podem ser transformadas em leis para atender determinado público. Entretanto, na versão disponível aos deputados federais e senadores, as "bases eleitorais" contam, além da capacidade de produzir legislação 
específica, com o apoio financeiro substancial por meio do Orçamento Impositivo, mas, nos municípios, elas dependem do "apoio" do prefeito em concretizar os pedidos dos vereadores.

O mundo da política não é um mundo marcado pela transparência ou da instantaneidade, nem lugar privilegiado de "homens pródigos e santos". A lógica que comanda a política é a lógica própria construída e utilizada na obtenção e na manutenção do poder. Quase sempre, os possíveis beneficiários advêm da ordem relacional estabelecida entre os eleitores, seus interesses pessoais que possam ser acolhidos por seus representantes políticos e transformados em algum tipo de aliança por meio do voto. É um movimento que está em contínua transformação e disputa. Lopez (2004, p. 156) endossa essa perspectiva, na medida em que "[...] o mundo público das leis impessoais e universais é constantemente confrontado com a necessidade de burlá-lo para atender às demandas do universo privado dos parentes, dos amigos, dos apadrinhados, dos aliados". É a reprodução da ordem estamental patrimonialista descrita por Faoro (2008) ainda na década de 50.

\section{Considerações finais}

O objetivo do artigo foi analisar a produção legislativa dos vereadores do município de Erechim (RS) nas funçôes principais de legislar, fiscalizar e administrar definidas pelas recomendaçóes da CGU, com a disponibilidade de orçamento público alocado para cobrir os gastos com o Legislativo Municipal. Os gastos do Legislativo estão amparados pela LRF e pela EMC n. ${ }^{\circ}$ 58/2009 (BRASIL, 2009), que os definem em até $6 \%$ do orçamento (no caso de Erechim). Tais gastos foram comparados com o percentual anotado nos orçamentos dos municípios de Bento Gonçalves (RS), Chapecó (SC), Concórdia (SC), Lages (SC), Lajeado (RS), Passo Fundo (RS), Pato Branco (PR) e Santa Cruz do Sul (RS), similares em população.

Foi possível inferir que há viabilidade técnica para a redução do número de vereadores na previsão orçamentária e nos gastos orçamentários com a Câmara de Vereadores de Erechim, atualmente equivalente a 3,7\% do orçamento municipal, enquanto a média dos municípios pesquisados foi de 2,4\%. Esse fator reflete no número de vereadores, no número de habitantes por vereador e nos recursos disponibilizados para cada vereador, embora a problemática não seja, à primeira vista, o número de vereadores, mas sim o limite de gastos, na medida em que os valores orçados estão sendo parcialmente utilizados, e as "sobras" estão sendo devolvidas no final de cada ano civil. Contudo, a prática de orçar valores acima das necessidades 
reais da casa legislativa congela os recursos que não podem ser utilizados de imediato para outras necessidades da administração municipal.

Além disso, observou-se a necessidade de reflexão e de mudanças na atuação dos parlamentares que permitam enfatizar projetos e políticas coletivas e estruturantes, visto que a análise verificou que $83 \%$ das açôes estão classificadas na função "outras" (pedidos de providências, moções, honrarias, congratulações etc.). Essa opção, não está na ordem das recomendações e prioridades elencadas pela CGU. Os dados revelam, em grande medida, a permanência de uma histórica estratégia de política clientelista, que se dá por meio do "atendimento" a demandas particularistas como argumento, justificação e cooptação sistemática dos eleitores nos pleitos eleitorais, mas que não ataca com políticas consistentes para enfrentar os problemas estruturais da cidade.

A partir dessas informações, com os devidos reparos e limites metodológicos e teóricos adotados no presente estudo, acredita-se que a temática pode ser ampliada a fim de elaborar análises embasadas em dados empíricos e produzir conhecimentos sobre os custos financeiros da democracia para os contribuintes, assim como para refletir sobre a qualidade das leis produzidas e das açóes dos vereadores e auxiliar o rompimento com a viciosa política clientelista, visando ampliar a transparência das questôes relacionadas à gestão do Estado ao colocar esses gastos amparados pela sociedade sob o escrutínio, debate e controle públicos.

Além disso, a atuação política dos representantes deve se pautar em projetos coletivos. O exercício da política está amparado demasiadamente na remuneração como profissão, na transferência de recursos da sociedade, os quais, na maioria das vezes, sustentam privilégios aviltantes em face à realidade social da maioria dos eleitores. Esse modelo é quase nulo na contribuição para a elaboração de instrumentos e processos que induzam a participação cidadã, a fim de promover o desenvolvimento ampliado da sociedade e de descriminalizar o exercício da política e consolidar a democracia como valor civilizatório.

- Eliziário Toledo é Doutor em Desenvolvimento Sustentável pela Universidade de Brasília. E-mail: enbtoledo@gmail.com.

Giovanni Menegazzo é Mestre em Administração pela Univrsidade Federal de Santa Catarina. É Engenheiro Mecânico na Universidade de Passo Fundo e Consultor Empresarial. E-mail: giovannidme@yahoo.com. 


\section{- Humberto José da Rocha é Doutor em Ciências Sociais pela Universidade Estadual de Campinas. É Professor Adjunto no Curso de Licenciatura em Ciências Sociais e no Mestrado em História na Universidade Federal da Fronteira Sul. E-mail: humberto.rocha@, uffs.edu.br}

\section{Referências}

ABRANCHES, Sérgio. Presidencialismo de coalizão: o dilema institucional brasileiro. Dados, v. 31, n. 1, p. 3-35, 2003.

ARRETCHE, Maria Teresa da Silva. Tendências no estudo sobre avaliação. In: RICCO, Elizabeth M. Avaliação de políticas sociais: uma questão em debate. São Paulo: Cortez, 1998. p. 29-39.

BAQUERO, Marcelo; VASCONCELOS, Camila. Crise de representaçáa política, o surgimento da antipolítica e os movimentos antipartidarismo no Brasil. In: ENCONTRO DO COMPOLÍTICA, 5., 2013, Curitiba. Anais... Curitiba, 2013. p. 1-21. Disponivel em: <http:/www.compolitica.org/home/wp-content/uploads/2013/05/GT06-Cultura-politicacomportamento-e-opiniao-publica-MarcelloBaquero.pdf>. Acesso em: 27 nov. 2019.

BENEVIDES, Maria Vitória de Mesquita. Democracia e Cidadania. In: BOAS, R. V. Participação popular nos governos locais. São Paulo: Pólis, 1994. p. 87-110.

BENTO GONÇALVES. Câmara de Vereadores. Lei Orçamentária Anual de Bento Gonçalves. Bento Gonçalves: Câmara de Vereadores, 2018. Disponivel em: <http://sapl.camarabento.rs.gov.br/media/sapl/public/materialegislativa/2018/21559/plo_2018_169. pdf>. Acesso em: 18 ago 2019.

BRASIL. Ministério do Planejamento. Orçamentos da União: Exercício Financeiro 2019. Projeto de Lei Orçamentária. Brasília: Ministério do Planejamento, 2019. v. 1. Disponivel em: $<$ https://www.google.com/url?sa=t\&rct=j\&q=\&esrc=s\&source=web\&cd=2\&ved=2ahUKEwjE5NKb 7NXgAhUYK7kGHT9kBwoQFjABegQICRAC\&url=http\%3A\%2F\%2Fwww.planejamento.gov.br \%2Fassuntos\%2Forcamento-1\%2Forcamentos-anuais\%2F2019\%2Fploa\%2Fvolume-11.pdf\&usg=AOvVaw3By8bYp_uUYrp9>. Acesso em: 27 fev 2019.

BRASIL. Câmara dos Deputados. Orçamento para 2019 prevê R\$ 13,7 bilhóes para emendas parlamentares. [Portal da Câmara dos Deputados], 2018a. Disponivel em: <https://www2.camara.leg.br/camaranoticias/noticias/ADMINISTRACAO-PUBLICA/563128ORCAMENTO-PARA-2019-PREVE-R\$-13,7-BILHOES-PARA-EMENDAS-PARLA>. Acesso em: 26 fev. 2019.

BRASIL. Câmara dos Deputados. Conheça o valor do salário de um deputado e demais verbas parlamentares. [Portal da Câmara dos Deputados], 2018b. Disponivel em: 
<https://www2.camara.leg.br/camaranoticias/noticias/POLITICA/563464-CONHECA-OVALOR-DO-SALARIO-DE-UM-DEPUTADO-E-DEMAIS-V>. Acesso em: 28 fev. 2019.

BRASIL. Tribunal Superior Eleitoral. Eleiçốes 2018: TSE divulga montante total do Fundo Especial de Financiamento de Campanha. [Portal do Tribunal Superior Eleitoral], 2018c. Disponivel em: $<$ http://www.tse.jus.br/imprensa/noticias-tse/2018/Junho/eleicoes-2018-tse-divulga-montante-totaldo-fundo-especial>. Acesso em: 25 fev. 2019.

BRASIL. Emenda Constitucional 86, de 17 de março de 2015. Altera os arts. 165, 166 e 198 da Constituição Federal, para tornar obrigatória a execução da programação orçamentária que especifica. Brasília, 2015. Disponivel em: <http://www.planalto.gov.br/ccivil_03/Constituicao/Emendas/Emc/emc86.htm>. Acesso em: 28 fev. 2019.

BRASIL. Emenda Constiticional 58, de 23 de setembro de 2009. Altera a redação do inciso IV do caput do art. 29 e do art. 29-A da Constituição Federal, tratando das disposiçóes relativas à recomposição das Câmaras Municipais. Brasília, 2009. Disponivel em: <http://www.planalto.gov.br/ccivil_03/Constituicao/Emendas/Emc/emc58.htm>. Acesso em: 27 fev. 2019.

BRASIL. Lei Complementar no 101, de 4 de maio de 2000. Estabelece normas de finanças públicas voltadas para a responsabilidade na gestão fiscal e dá outras providências. Brasília, 2000. Disponivel em: <http://www.planalto.gov.br/ccivil_03/leis/LCP/Lcp101.htm>. Acesso em: 25 fev. 2019.

BRASIL. Constituição Federal de 1988. Brasília, 1988. Disponivel em: <http://www.planalto.gov.br/ccivil_03/constituicao/constituicaocompilado.htm>. Acesso em: 28 fev. 2019.

BRESSER-PEREIRA, Luís. Carlos. Transição, consolidação cemocrática e cevolução capitalista. Dados, v. 54, n. 2, p. 223-258, 2011. Disponivel em: $<$ http://www.scielo.br/scielo.php?script=sci_abstract\&pid=S0011-

$52582011000200001 \& \operatorname{lng}=$ pt\&nrm=iso $>$. Acesso em 28 fev. 2019.

CARVALHO, José Murilo de. Mandonismo, coronelismo, clientelismo: cma ciscussão conceitual. Dados, v. 40, $\quad$ n. $2,1997 . \quad$ Disponivel em: $<$ https://www.scielo.br/scielo.php?script=sci_isoref\&pid=S0011$52581997000200003 \& \operatorname{lng}=$ en\&tlng=pt $>$. Acesso em: 22 maio 2020.

CHAPECÓ. Câmara de Vereadores. Lei Orçamentária Anual de Chapecó. Chapecó: Câmara de Vereadores, 2019. Disponivel em: < https://web.chapeco.sc.gov.br/documentos/?f=/ Documentos/Acesso à Informação/Auditorias/2019/Lei orçamentaria Anual 2019.pdf >. Acesso em: 14 ago. 2019.

CONCÓRDIA. Câmara de Vereadores. Lei Orçamentária Anual de Concórdia. Concórdia: Câmara de $\quad 2018 . \quad$ Dereadores, em: $<$ https://www.cloudsoftcam.com.br/CONCORDIA/anexos/2018103116243515410138751bd790. pdf>. Acesso em: 15 ago. 2019.

CONTROLADORIA GERAL DA UNIÃO (CGU). O vereador e a fiscalização dos recursos públicos municipais. [Portal do Governo Federal], 2011. Disponivel em: <http://www.cgu.gov.br/cartilhavereadores>. Acesso em: 26 fev. 2019.

DA MATTA, Roberto. Carnavais, malandros e heróis: para um sociologia do dilema brasileiro. Rio de Janeiro: Rocco, 1997. 
DELLEY, Jean-Daniel. Congresso Internacional de Legística: Qualidade da Lei e Desenvolvimento. In: MINAS GERAIS. Legística: qualidade da lei e desenvolvimento. Belo Horizonte: Assembleia Legislativa de Minas Gerais, 2009. p. 181-222. Disponivel em: <https:/www.almg.gov.br/export/sites/default/consulte/publicacoes_assembleia/obras_referencia/arq uivos/pdfs/legistica/integra.pdf>. Acesso em: 28 fev. 2019.

ERECHIM. Câmara Municipal de Vereadores. Vereadores em Exercício 2017/2020. [Portal da Câmara Municipal de Vereadores de Erechim], 2020. Disponível em: <https://www.erechim.rs.leg.br/processo-legislativo/index/edis>. Acesso em: 21 maio 2020.

ERECHIM. Lei Orçamentária Anual 2019. Erechim: Prefeitura Municipal de Erechim, 2019. Disponivel em: <https://uploads.preferechim2.astrusweb.dataware.com.br/uploads.preferechim2.astrusweb.dataware .com.br/uploads/public_bills/1318/62fa32454e5a53e95a7161ef553c0a43.pdf>. Acesso em: 17 ago. 2019.

ERECHIM. Portal da Transparência. Erechim: Prefeitura Municipal de Erechim, 2018. Disponivel em: <http://www.erechim.rs.gov.br:81/sys523/publico/publicacoes.xhtml>. Acesso em: 7 mar. 2019.

FAORO, Raimundo. Os donos do poder: formação do patronato político brasileiro. São Paulo: Globo, 2008.

HIRSCHMAN, Albert. De consumidor à cidadão: atividade privada e participação na vida pública. São Paulo: Brasiliense, 1983.

INSTITUTO BRASILEIRO DE GEOGRAFIA E ESTATÍSTICA (IBGE). IBGE Cidades. IBGE: 2018. Disponivel em: <https://cidades.ibge.gov.br/brasil/rs/erechim/panorama>. Acesso em: 6 mar. 2019.

KOTHE, Flávio. Nosso olhar vai além de nossos olhos. In: BUARQUE, Cristóvam; ALEMIDA, Francisco; NAVARRO, Zander. Brasil, brasileiro: por que somos assim? Brasília: DF, 2017. p. 105122.

LAGES. Lei no 4.309, de 17 de dezembro de 2018. Estima a Receita e Fixa a Despesa do Município de Lages para o exercício de 2019. Lages, 2018. Disponivel em: <https://leismunicipais.com.br/a1/sc/l/lages/lei-ordinaria/2018/431/4309/lei-ordinaria-n-43092018-estima-a-receita-e-fixa-a-despesa-do-municipio-de-lages-para-o-exercicio-de-2019?q=4309.>. Acesso em: 15 ago. 2019.

LAJEADO. Lei $n^{\circ}$ 10.740, de 30 de novembro de 2018. Estima a receita e Fixa a Despesa do Município de Lajeado para o exercício de 2019. Lajeado, 2018. Disponivel em: <https://leismunicipais.com.br/lei-orcamentaria-anual-lajeado-rs>. Acesso em: 16 ago. 2019.

LOPEZ, Félix. A política cotidiana dos vereadores e as relações entre executivo e legislativo em âmbito municipal: o caso do município de Araruama. Revista Sociologia Política, n. 22, p. 153-177, 2004.

MARTINS, José de Souza. O brasileiro das travessias. In: BUARQUE, Cristóvam; ALEMIDA, Francisco; NAVARRO, Zander. Brasil, brasileiros: por que somos assim? Brasília: Verbena Editora, 2017. p. 147-156.

MENEGUIN, Fernando. Avaliação de impacto legislativo no Brasil. Latin American and Caribbean Law and Economics Association - Annual Papers, 2010.

MINAS GERAIS. Assembléia Legislativa. Legística: qualidade da lei e desenvolvimento. Belo Horizonte: Assembleia Legislativa de Minas Gerais, 2009. Disponivel em: 
<https://www.almg.gov.br/export/sites/default/consulte/publicacoes_assembleia/obras_referencia/arq uivos/pdfs/legistica/integra.pdf >. Acesso em: 26 fev. 2019.

NAVARRO, Zander. Complacência é a marca que define o brasileiro. Folha de S. Paulo, 17 fev. 2019. Disponivel em: <https:/www1.folha.uol.com.br/ilustrissima/2019/02/complacencia-e-a-marca-quedefine-o-brasileiro-defende-sociologo.shtml>. Acesso em: 7 mar. 2019.

NAVARRO, Zander. O Brasil contra si mesmo: a complacência sociopolítica dos brasileiros. In: BUARQUE, Cristóvam; ALEMIDA, Francisco; NAVARRO, Zander. Brasil, brasileiros: por que somos assim? Brasília: Verbena Editora, 2017. p. 317-338.

NORTH, Douglas. Institutions, institutional change and economic performance. Cambridge: Cambridge University Press, 1990.

NUNES, Edson. A gramática política no Brasil: clientelismo e insulamento burocrático. Rio de Janeiro: Jorger Zahar, 2003.

PASSO FUNDO. Lei $n^{\circ} 5.385$, de 20 de dezembro de 2018. Estima a receita e autoriza a despensa do município de Passo Fundo para o exercício financeiro de 2019. Passo Fundo, 2018. Disponível em: <http://www.pmpf.rs.gov.br/files/transparencia/loa2019_lei53852018.pdf>. Acesso em: 16 ago. 2019.

PATO BRANCO. Câmara de Vereadores. Lei Orçamentária Anual de Pato Branco. Pato Branco: Câmara de Vereadores, 2019. Disponivel em: <http://camarapatobranco.com.br/legislacoes/5261/>. Acesso em: 14 ago. 2019.

QUANTO ganham os parlamentares pelo mundo? DW, 2018. Disponivel em: <https://www.dw.com/pt-br/quanto-ganham-os-parlamentares-pelo-mundo/g-45167763>. Acesso em 27 de fev 2019>. Acesso em: 28 fev. 2019.

ROSENTONE, Steve; LAZARUS, Edward. Third Parties in America: citizen response to major party failure. Princeton, N.J.: Princeton University Press, 1984.

SANTA CRUZ DO SUL. Lei no 8.096, de 20 de dezembro de 2018. Orça a receita e fixa a despesa do Município para o Exercício de 2019. Santa Cruz do Sul, 2018. Disponível em: <http://portaltransparencia.camarasantacruz.rs.gov.br:1080/multi24/sistemas/transparencia/index?se cao=buscarnosite>. Acesso em: 16 ago. 2019.

SEN, Amartya. Desenvolvimento como liberdade. São Paulo: Companhia das Letras, 2000.

ZIZEK, Slavoj. A coragem da desesperança. Rio de Janeiro: Zahar, 2019.

Texto recebido em 22 de novembro de 2019. Aprovado em 23 de julho de 2020. 